\title{
BIMBINGAN BELAJAR EAGLE NEST MELALUI PEMBELAJARAN DARING DALAM MASA PANDEMI
}

\author{
Wiyun Philipus Tangkin ${ }^{1}$, Wiputra Cendana ${ }^{2}$ \\ ${ }^{1}$ Universitas Pelita Harapan \\ ${ }^{2}$ Universitas Pelita Harapan
}

wiyun.tangkin@uph.edu; wiputra.cendana@uph.edu

\begin{abstract}
Abstrak
Bimbingan belajar Eagle Nest adalah gerakan peduli akan pentingnya pendidikan untuk semua kalangan, yang dimulai dari tahun 2017 hingga saat ini. Bimbingan belajar ini melayani anak-anak yang tinggal di daerah Griya Karawaci dengan tingkat perekonomian menengah ke bawah (kaum marginal). Berdasarkan dari kebutuhan tersebut maka UPH-Teachers College mengadakan Bimbingan Belajar di Perum Griya Karawaci, CurugTangerang. Bimbingan Belajar ini bertujuan untuk memberikan pembekalan berupa pembelajaran tambahan serta pendampingan anak belajar dari tingkat TK, SD, SMP, dan SMA. Materi yang diajarkan disesuaikan dengan materi sekolah masing-masing siswa. Metode belajar bermain akan diterapakan untuk siswa TK-SD kelas 3 sedangkan untuk SD kelas 4 hingga seterusnya akan disesuaikan dengan materi yang diajarkan. Kegiatan Bimbingan Belajar ini dilakukan 2 kali pertemuan per minggu dalam bentuk pembelajaran daring, dan yang mengajar adalah mahasiswa Fakultas Ilmu Pendidikan - Teachers College yang sudah diseleksi sebelumnya. Adapun hasil evaluasi setelah berjalan sejak awal hingga pertengahan tahun 2021 yaitu kegiatan ini membantu siswa dalam meningkatkan kemampuan membaca, menulis, dan berhitung bagi siswa TK-SD dan meningkatkan kemampuan Matematika untuk siswa SMP-SMA. Kegiatan ini mampu meningkatkan kemampuan anak-anak bimbingan belajar secara holistis, bukan hanya secara akademik, tetapi juga karakter. Selain itu, mahasiswa yang melayani sebagai tutor juga dapat menjadikan kegiatan ini sebagai media untuk melatih keterampilan mengajar dan panggilannya sebagi guru yang dewasa.
\end{abstract}

Kata Kunci: Bimbingan belajar, marginal, siswa, pembelajaran daring.

\section{PENDAHULUAN}

Manusia adalah makhluk yang diciptakan memiliki akal budi. Berbeda dengan makhluk ciptaan lainnya. Melalui akal budi manusia dapat belajar untuk beradaptasi dan mengembangkan dirinya. Belajar adalah proses dalam pendidikan. Pendidikan merupakah bagian penting dalam kehidupan manusia. Melalui pendidikan, manusia dapat mengembangkan potensi dirinya dengan tujuan agar dapat hidup mandiri dan menjadi berguna bagi sesamanya. Dalam Undang-undang
Pendidikan Nasional No. 20 tahun 2003 menyatakan bahwa pendidikan merupakan usaha sadar dan terencana untuk mewujudkan suasana belajar dan proses pembelajaran agar peserta didik secara aktif mengembangkan potensi dirinya. Salah satu konsep agar siswa mampu mengembangkan potensi dirinya adalah dengan cara belajar. Belajar merupakan kebutuhan yang harus dipenuhi oleh siswa, karena dengan belajarlah siswa dapat memperoleh ilmu pengetahuan yang luas dan mampu mengaplikasikan dalam kehidupannya sehari-hari. 
PkM ini adalah bentuk kerjasama antara Gereja Baptis Indonesia dengan UPH-Teachers College Program Studi Pendidikan Guru Sekolah Dasar (PGSD) yang telah berlangsung sejak Agustus 2018. Bentuk kegiatan ini berupa kegiatan bimbingan belajar dengan nama Bimbingan Belajar Eagle Nest, dimana mahasiswa UPH-Teachers College yang bertugas sebagai pengajar (tutor) dan peserta didiknya adalah siswa-siswa TK-SMA yang telah dikumpulkan oleh Gereja Baptis Indonesia di daerah Perumahan Griya Karawaci, Curug (tinggal di sekitar perumahan tersebut). Kegiatan bimbingan belajar ini, berawal dari permohonan pihak Gereja Baptis Indonesia kepada UPH-Teachers College, untuk dapat mewujudkan kerinduan dalam mengambil bagian pelayanan masyarakat, khususnya kaum marginal, di daerah sekitar gereja terutama di bidang pendidikan. Keprihatinan tercetus saat mendengar sharing dari anggota Gereja yang tinggal di daerah setempat yang prihatin terhadap masyarakat sekitar, dimana anak-anak yang berperan sebagai siswa mengalami kesulitan belajar. Hal tersebut disebabkan oleh beberapa faktor dan salah satu di antaranya adalah status ekonomi keluarga yang relatif rendah di daerah tersebut.

Tingkat kemampuan ekonomi yang lemah bukan saja memberikan kesempatan yang kurang dalam memperoleh pendidikan berkualitas di sekolah namun juga kesempatan di luar sekolah. Orang tua tidak mampu memberikan les tambahan atau bimbingan belajar sehingga memperparah keterpurukan dalam memahami materi pembelajaran di sekolah. Chotimah, dkk., (2017), mengatakan bahwa keadaan ekonomi keluarga erat hubungannya dengan hasil belajar siswa. Kelas sosial ekonomi berpengaruh terhadap pendidikan yang dialami oleh golongan tertentu, termasuk pengalaman pembelajaran dan ruang lingkup materi yang diperoleh terlepas dari standar pendidikan nasional yang dikeluarkan oleh pemerintah. Akibatnya, mereka tidak menyukai kegiatan belajar di sekolah. Sudah tentu, jika tidak menyukai sekolah, maka dapat diprediksikan hasil belajar pun tidak maksimal. Hal yang sama juga dikatakan oleh Zaini, dkk. (2015), bahwa keberhasilan belajar seorang siswa dipengaruhi oleh berbagai faktor, baik faktor yang berasal dari dalam diri (internal) maupun dari luar (eksternal). Faktor eksternal biasanya dipengaruhi oleh keadaan perekonomian keluarga. Dampak dari rendahnya kasadaran siswa terhadap tanggung jawabnya untuk belajar, maka akan sangat memengaruhi masa depannya, masa depan nantinya akan memengaruhi keadaan sosial sekitarnya, termasuk keluarganya. Jika hal ini terusmenerus berlangsung tanpa adanya solusi maka akan menjadi bom waktu dimana akan tercipta komunitas yang rendah tingkat sumber daya manusianya. Dampaknya bisa kemana-mana.

Penyebaran virus covid-19 secara masif mengakibatkan pandemi di berbagai belahan dunia yang berdampak bagi setiap elemen masyarakat. Masyarakat dipaksa untuk tidak melakukan pertemuan dalam skala besar guna memutus rantai penyebaran virus. Hal tersebut tentunya berlaku juga bagi sistem pendidikan saat ini, salah satunya pembelajaran yang dilakukan secara tatap muka berubah menjadi tatap maya atau daring. Menggunakan digital teknologi sebagai jembatan interaksi adalah cara yang efektif dipakai saat pandemi ini. Pembelajaran daring merupakan suatu sistem pembelajaran yang dilaksanakan dengan cara tidak bertatap muka secara langsung, namun dengan menggunakan platform ketika proses pembelajaran dan dapat dilakukan meskipun jarak jauh (Sourial, Longo, Vedel, \& Schuster, 2018, p. 498). Hal ini sejalan dengan pendapat Simanjuntak (2019) bahwa pembelajaran daring juga merupakan pembelajaran yang memanfaatkan penggunaan teknologi yang ada untuk melakukan proses belajar mengajar. Pembelajaran daring yang diterapkan bersifat fleksibel, dalam artian dapat dilakukan dimana dan kapanpun ketika siswa mengakses sumber belajar atau disaat melakukan proses pembelajaran. Menurut Oktavian \& Aldya (2020), efektivitas pembelajaran daring memiliki aspek bahwa guru lebih bisa menyesuaikan interaksi kepada siswa seperti memberikan pembelajaran yang bersifat fleksibel, diskriptif dengan mengadakan diskusi antar siswa dan guru, interaktif, dan reflektif.

Sistem pembelajaran yang berubah dari tatap muka menjadi tatap maya (daring) ternyata membuat motivasi siswa semakin menurun dalam belajar. Ditambah lagi dengan kurangnya peran orang tua untuk mendampingi siswa untuk belajar 
membuat siswa semakin tidak termotivasi untuk belajar.

Materi pelajaran yang semakin sulit juga menjadi pengaruh orang tua sulit mendampingi anak. Hal ini selaras dengan yang dikatakan oleh Bakhtiyar, (2019), bahwa partisipasi orang tua dalam proses pendidikan masih tergolong rendah. Akibatnya proses belajar anak belum tergolong menyenangkan, sehingga anak belum dapat mengembangkan potensinya. Kendati sudah ada guru sebagai pendamping dan pembimbing anakanak belajar, namun bimbingan dan pendampingan belajar perlu dilanjutkan setelah jam sekolah. Pengkondisian belajar yang dilakukan secara berkesinambungan akan membantu siswa mengembangkan potensinya. Berdasarkan permasalahan tersebut maka dapat disimpulkan bahwa anak membutuhkan pendampingan atau bimbingan dalam belajar, terutama setelah jam sekolah. Belajar tidak seharusnya dibatasi oleh jam sekolah, tetapi proses belajar itu harusnya berlangsung secara terus menerus bahkan sepanjang hidup.

Menurut Qomaruddin, (2017), bimbingan adalah bantuan yang diberikan kepada seseorang agar mengembangkan potensi-potensi yang dimiliki di dalam dirinya sendiri dalam mengatasi persoalanpersoalan sehingga dapat menentukan sendiri jalan hidupnya secara bertanggungjawab tanpa harus bergantung dengan orang lain. Dengan kata lain bimbingan bertujuan untuk memandirikan orang yang dibimbing. Berarti akan ada masa dimana anak akan hidup mandiri tanpa bergantung dengan orang lain termasuk oleh orang tuanya. Oleh karena itu pentingnya membimbing anak agar mandiri, dan hal ini sebaiknya dilakukan dalam rentang usia 0-18 tahun.

Bimbingan belajar sebaiknya dilakukan terus menerus secara berkesinambungan agar prestasi belajar anak dapat optimal. Teori yang mendasari bimbingan belajar ini adalah teori yang diusung oleh Lev Vygotsky, yaitu Teori Konstruktivisme Sosial. Dalam teorinya, Vygotsky mengatakan bahwa di samping guru, teman sebaya juga berpengaruh penting pada perkembangan kognitif anak. Dalam hal ini Vygotsky menjelaskan bahwa satu anak bisa lebih efektif membimbing anak lainnya melewati ZPD (Zone of Proximal Development) atau area dimana siswa tidak dapat mengembangkan kognitifnya tanpa bantuan dari orang lain), dengan menyediakan scaffolding (alat bantu untuk membimbing siswa belajar) yang sesuai. Bimbingan belajar dengan menyediakan tutor sebagai pendamping/ pembimbing merupakan salah satu cara untuk membantu siswa meningkatkan perkembangan kognitifnya. Berikut ini adalah gambar mengenai ZPD:

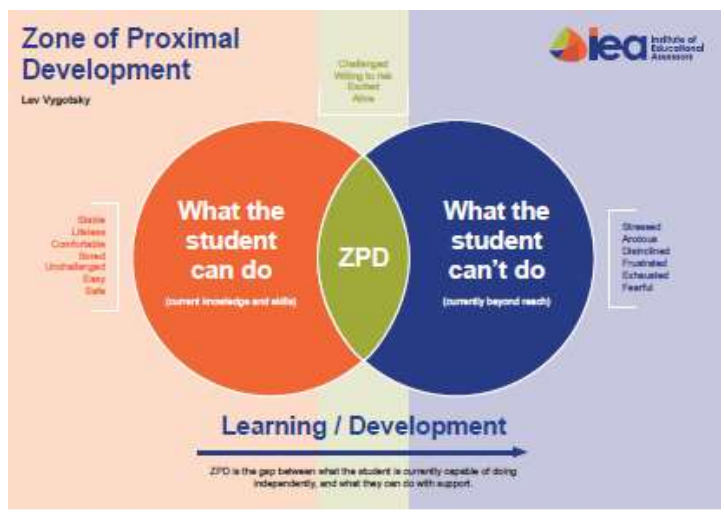

Gambar 1. Zone of Proximal Development

Pada gambar 1 (menggunakan pemisalan Diagram Venn) di atas, menjelaskan bahwa ada area dimana siswa bisa melakukan (warna oranye), area siswa tidak bisa (warna biru), dan area siswa membutuhkan bantuan orang lain untuk bisa (irisan berwarna hijau). Pada area irisan itulah siswa membutuhkan orang lain di luar dari dirinya untuk membantu mengembangkan potensinya berupa ranah kognitif, afektif, dan juga psikomotorik.

Dalam bimbingan belajar ini menggunakan istilah tutoring dimana tutor sebagai pembimbing yang akan mendampingi dan mengajar siswa. Santrock, (2011) dalam bukunya mengatakan bahwa tutoring pada dasarnya adalah pelatihan kognitif antara pakar dan pemula. Tutoring bisa terjadi antara orang dewasa dan anak-anak, atau anak yang lebih pandai dengan anak yang kurang pandai. Dengan kata lain tutoring adalah pendampingan belajar yang dilakukan oleh orang yang sudah lebih dulu tahu terhadap siswa yang belum tahu. Mengajari orang lain tentang sesuatu adalah cara terbaik untuk belajar. Prinsip inilah yang dialami oleh setiap guru. Ini sesuai dengan pepatah bahwa semakin digunakan semakin bertambah. Begitulah cara kerja ilmu, semakin dibagi maka sebenarnya semakin mahir dalam pengetahuan tersebut. Tuhan menciptakan cara kerja otak manusia sedemikian 
baik, dimana cara kerjanya, pengetahuan manusia tidak akan habis sekalipun dibagikan. Hal ini dapat terjadi karena proses pengulangan di dalam otak.

Proses pengulangan dalam belajar sesuai dengan teori Pemrosesan Informasi yang diusung oleh Robert Gagne (1985), dalam Roediger, Henry., (2013). Teori ini menjelaskan bahwa pembelajaran adalah hal yang sangat penting dalam perkembangan. Hal ini dapat dijelaskan melalui gambar Proses metacognition berikut ini:

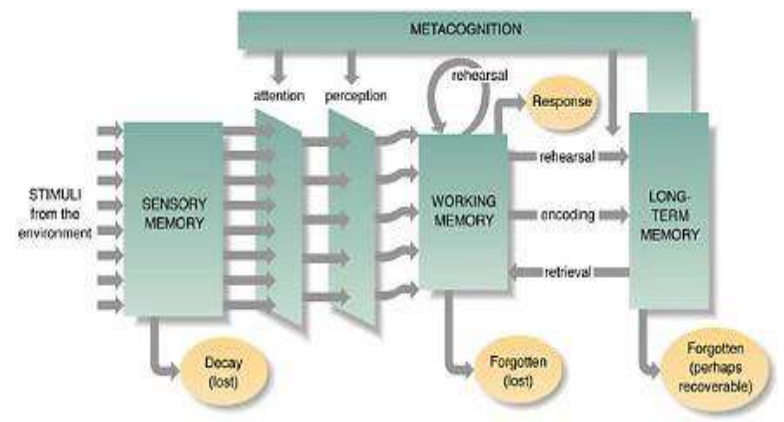

Gambar 2. Proses Metacognition

Proses metacognition pada gambar 2 menjelaskan mengenai alur informasi yang diterima oleh otak. Pada working memory terjadi beberapa proses yang dapat dilakukan agar informasi dapat tinggal lama di dalam long term memory. Beberapa proses dalam working memory tersebut yaitu proses rehearsal (pengulangan), encoding (pengkodean), dan retrieval (mengingat kembali). Jika informasi tidak melalui salah satu atau beberapa proses dalam working memory maka informasi hanya akan tinggal sebagai short term memory (ingatan jangka pendek/ tidak bertahan lama/ dilupakan). Semakin sering informasi diulang atau diingat maka akan sangat mudah informasi itu bertahan dalam dalam ingatan. Proses inilah yang sangat diharapkan dapat dialami oleh tutor sebagai mahasiswa calon guru.

Dengan kata lain, dampak dari bimbingan belajar dengan metode tutoring tidak hanya dirasakan oleh siswa tetapi juga oleh mahasiswa yang berperan sebagai pengajar/ pembimbing (tutor). Tutor mendapatkan manfaat juga karena dapat langsung mempraktekkan belajar mengajar, proses mengulang kembali materi pembelajaran yang sedang diajarkan dan sudah pernah didapatkan, mengenal karakteristik siswa melalui interaksi, dan lain sebagainya. Pengalaman ini tentunya menjadi bekal yang sangat bermanfaat bagi mahasiswa calon guru sebelum menjalani panggilan mereka nantinya saat menjadi guru.

Bimbingan belajar ini bersifat non formal. Proses belajar tidak seperti di sekolah. Siswa belajar dengan kondisi lebih santai, baju bebas santai, dapat berinteraksi dengan teman sebaya, menganggap tutor seperti kakak, metode pembelajarannya juga disesuaikan dengan jenjang pendidikan siswa. Ice breaking atau games merupakan bagian dari proses belajar pada bimbingan belajar ini, belajar sambil bermain, bercanda, termasuk bercerita. Hal ini membantu siswa lebih mudah untuk mengalami dan menikmati proses belajar karena tidak tertekan atau tegang.

Pembelajaran juga dibagi dalam kelompok. Pembagiannya disesuaikan dengan jenjang pendidikan siswa. Paling banyak per kelompok sekitar 4-5 siswa. Model pembelajaran secara berkelompok ini dikenal dengan model pembelajaran kooperatif. Menurut Slavin, dalam Nurdyansyah \& Fahyuni (2016), pembelajaran kooperatif menggalakkan siswa berinteraksi secara aktif dan positif dalam kelompok, memperbolehkan terjadinya pertukaran ide, dalam suasana yang nyaman sesuai dengan falsafah konstruktivisme. Pembelajaran kooperatif dapat meningkatkan kualitas proses belajar dan hasil belajar siswa. Hal tersebut dikemukakan Robert E. Slavin dalam Wina Sanjaya (2008), bahwa terdapat dua alasan yaitu: 1) Berdasarkan hasil beberapa penelitian yang dilakukan oleh pakar pendidikan membuktikan bahwa model pembelajaran kooperatif dapat meningkatkan prestasi belajar siswa sekaligus dapat meningkatkan kemampuan hubungan sosial, menumbuhkan sikap toleransi dan menghargai pendapat orang lain; 2) Model pembelajaran kooperatif secara teoritis dapat merealisasikan kebutuhan siswa dalam belajar berpikir kreatif, memecahkan masalah, dan mengintegrasikan pengetahuan dengan pengalaman.

Tujuan diadakannya PkM ini adalah untuk membantu meningkatkan kemampuan akademik siswa TK-SD kelas 3 (membaca, menghitung, dan menulis), dan siswa SD kelas 4-SMA (Matematika, IPA, dan Bahasa Inggris) melalui pendampingan belajar. Kegiatan ini bukan hanya untuk meningkatkan kemampuan akademik siswa 
melainkan juga menciptakan komunitas yang belajar berkesinambungan setelah pembelajaran dari sekolah. Kegiatan yang akan dilaksanakan adalah siswa belajar didampingi oleh tutor untuk SD kelas 4-SMA dan pendampingan siswa aktif dalam bentuk permainan dan aktivitas untuk TK-SD kelas 3. Pembagian ini disesuaikan dengan karakteristik jenjang pendidikan siswa sebagai peserta didik dalam bimbingan belajar ini.

\section{METODE}

Berikut ini adalah metode pelaksanaan $\mathrm{PkM}$ bimbingan belajar di Curug Tangerang: 1) Ketua PkM merekrut mahasiswa calon guru yang akan mengajar (tutor) dan menunjuk diantaranya sebagai PiC tutor; 2) Ketua PkM mem-briefing seluruh tutor, mengenai tujuan kegiatan dan bagaimana pelaksanaannya; 3) Tutor menyusun materi; 4) Ketua PkM dan PiC tutor membagi tutor untuk mengajar siswa TK, SD kelas 1-3, SD kelas 4-6, SMP, SMA; 5) Bimbingan belajar berlangsung; 6) Ketua PkM mengobservasi dan mendampingi para tutor setiap mengajar dan memberikan umpan balik; 7) Tutor melakukan evaluasi pengajaran setiap akhir kelas; 8) Para tutor meminta evaluasi kegiatan dari siswa dan orang tua untuk keseluruhan bimbingan belajar yang sudah terlaksana; 9) Saran, evaluasi, dan refleksi tutor, refleksi orang tua, dan refleksi siswa, merupakan masukan untuk memperbaiki program bimbingan belajar yang akan dilaksanakan semester berikutnya.

\section{HASIL DAN PEMBAHASAN}

\section{Pelaksanaan PKM}

Berikut adalah skema pelaksanaan PkM yang telah dilaksanakan:

\begin{tabular}{|c|l|l|l|l|}
\hline No & Kegiatan & Waktu & Tutor & Peserta \\
\hline 1 & Mengajar & 18 Jan 2021 & 2 & 15 \\
\hline 2 & Mengajar & 19 Jan 2021 & 4 & 10 \\
\hline 3 & Mengajar & 25 Jan 2021 & 3 & 10 \\
\hline 4 & Mengajar & 26 Jan 2021 & 4 & 7 \\
\hline 5 & Mengajar & 27 Jan 2021 & 3 & 8 \\
\hline 6 & Mengajar & 1 Feb 2021 & 3 & 7 \\
\hline 7 & Mengajar & 2 Feb 2021 & 5 & 14 \\
\hline 8 & Mengajar & 3 Feb 2021 & 4 & 8 \\
\hline 9 & Mengajar & 8 Feb 2021 & 3 & 9 \\
\hline 10 & Mengajar & 9 Feb 2021 & 5 & 12 \\
\hline 11 & Mengajar & 10 Feb 2021 & 4 & 7 \\
\hline
\end{tabular}

\begin{tabular}{|c|c|c|c|c|}
\hline No & Kegiatan & Waktu & Tutor & Peserta \\
\hline 12 & Mengajar & 15 Feb 2021 & 3 & 7 \\
\hline 13 & Mengajar & 16 Feb 2021 & 5 & 13 \\
\hline 14 & Mengajar & 17 Feb 2021 & 4 & 8 \\
\hline 15 & Mengajar & 1 Mar 2021 & 6 & 11 \\
\hline 16 & Mengajar & 2 Mar 2021 & 9 & 10 \\
\hline 17 & Mengajar & 3 Mar 2021 & 8 & 12 \\
\hline 18 & Mengajar & 8 Mar 2021 & 9 & 13 \\
\hline 19 & Mengajar & 9 Mar 2021 & 12 & 12 \\
\hline 20 & Mengajar & 10 Mar 2021 & 10 & 19 \\
\hline 21 & Mengajar & 12 Mar 2021 & 10 & 20 \\
\hline 22 & Mengajar & 13 Mar 2021 & 12 & 24 \\
\hline 23 & Mengajar & 14 Mar 2021 & 9 & 20 \\
\hline 24 & Mengajar & 15 Mar 2021 & 8 & 19 \\
\hline 25 & Mengajar & 16 Mar 2021 & 9 & 17 \\
\hline 26 & Mengajar & 17 Mar 2021 & 8 & 10 \\
\hline 27 & Mengajar & 19 Mar 2021 & 9 & 26 \\
\hline 28 & Mengajar & 22 Mar 2021 & 9 & 27 \\
\hline 29 & Mengajar & 23 Mar 2021 & 12 & 26 \\
\hline 30 & Mengajar & 24 Mar 2021 & 9 & 18 \\
\hline 31 & Mengajar & 27 Mar 2021 & 12 & 19 \\
\hline 33 & Mengajar & 28 Mar 2021 & 9 & 9 \\
\hline 34 & Mengajar & 5 Apr 2021 & 9 & 25 \\
\hline 35 & Mengajar & 6 Apr 2021 & 12 & 21 \\
\hline 36 & Mengajar & 7 Apr 2021 & 10 & 23 \\
\hline 37 & Mengajar & 20 Apr 2021 & 12 & 19 \\
\hline 38 & Mengajar & 21 Apr 2021 & 9 & 14 \\
\hline 39 & Mengajar & 26 Apr 2021 & 9 & 18 \\
\hline 40 & Mengajar & 3 Mei 2021 & 9 & 17 \\
\hline 41 & Mengajar & 4 Mei 2021 & 12 & 19 \\
\hline 42 & Mengajar & 5 Mei 2021 & 9 & 15 \\
\hline 43 & Ibadah & 17 Mei 2021 & 12 & 20 \\
\hline 44 & $\begin{array}{l}\text { Acara } \\
\text { Kebersamaan } \\
\text { (Penutupan } \\
\text { semester) }\end{array}$ & 20 Mei 2021 & 12 & 27 \\
\hline
\end{tabular}

Gambar 3. Kegiatan Bimbingan Belajar

Pelaksanaan PKM ini diadakan sebanyak 44 kali pertemuan. Proses belajar mengajar dilakukan 3 kali dalam seminggu yaitu setiap hari Senin, Rabu, dan Kamis. Diadakan mulai tanggal 18 Januari - 20 Mei 2021. Bekerja sama dengan Gereja Baptis Indonesia di daerah Perumahan Griya Karawaci, Curug. Bimbingan belajar dilaksanakan dengan menggunakan platform zoom meeting. Kegiatan bimbingan belajar dilakukan pukul 19.0021.00 WIB. Pemilihan waktu itu sesuai kesepakatan antara pihak orang tua siswa dan juga mahasiswa sebagai tutor. 


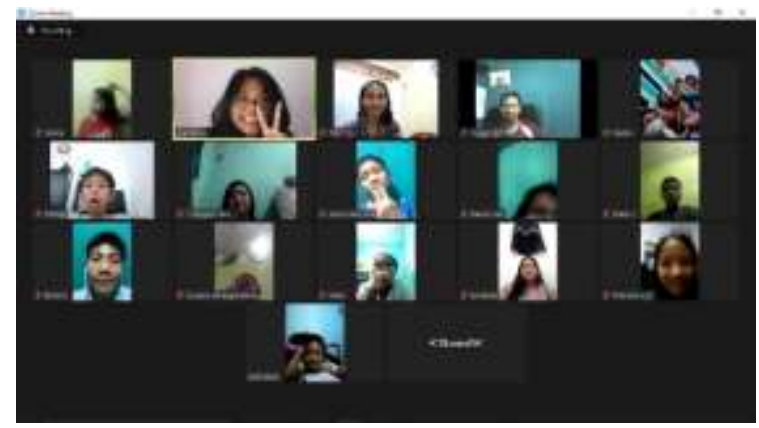

Gambar 4. Kegiatan Bimbingan Belajar 18 Jan 2021

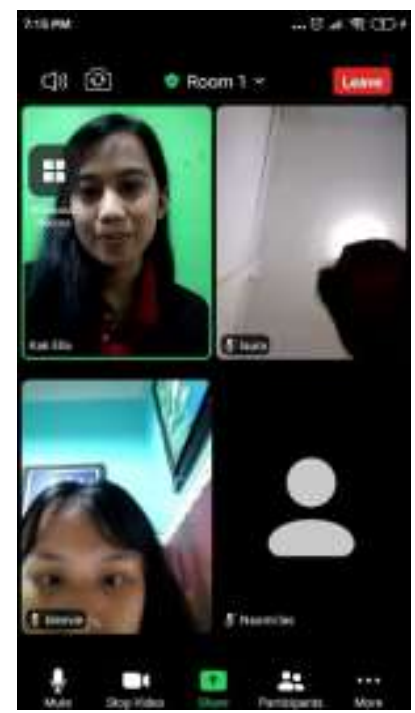

Gambar 5. Kegiatan Bimbel 19 Jan 2021

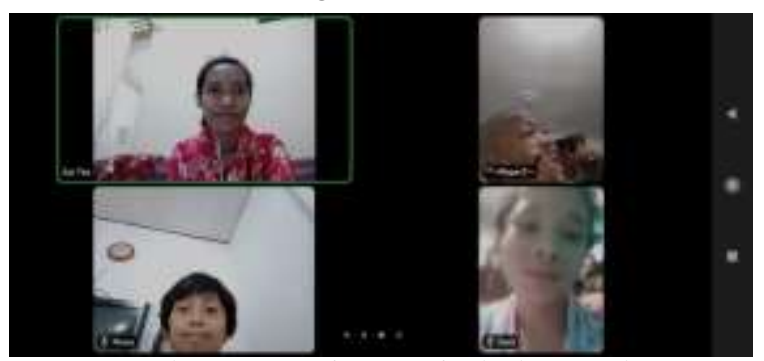

Gambar 6. Kegiatan Bimbel 15 Feb 2021

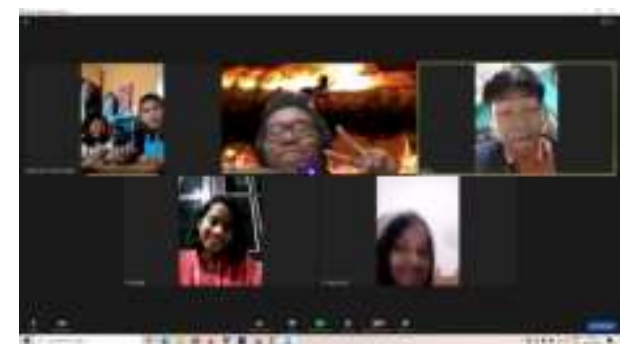

Gambar 7. Kegiatan Bimbel 16 Feb 2021

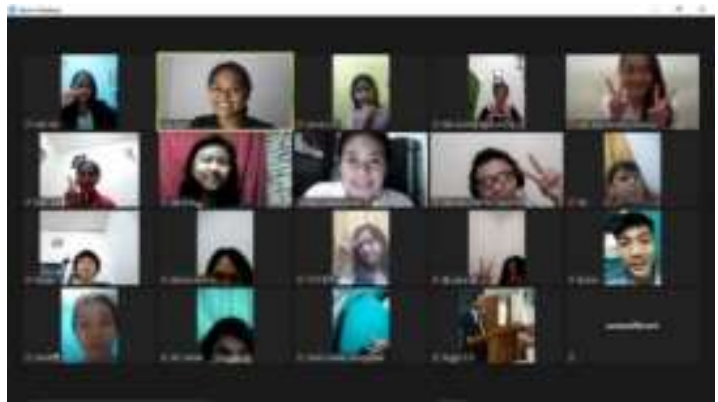

Gambar 8. Kegiatan Bimbingan Belajar 2 Mar 2021

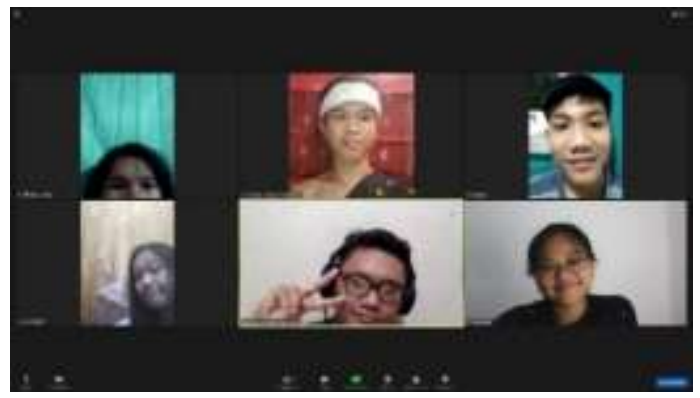

Gambar 9. Kegiatan Bimbingan Belajar 3 Mar 2021

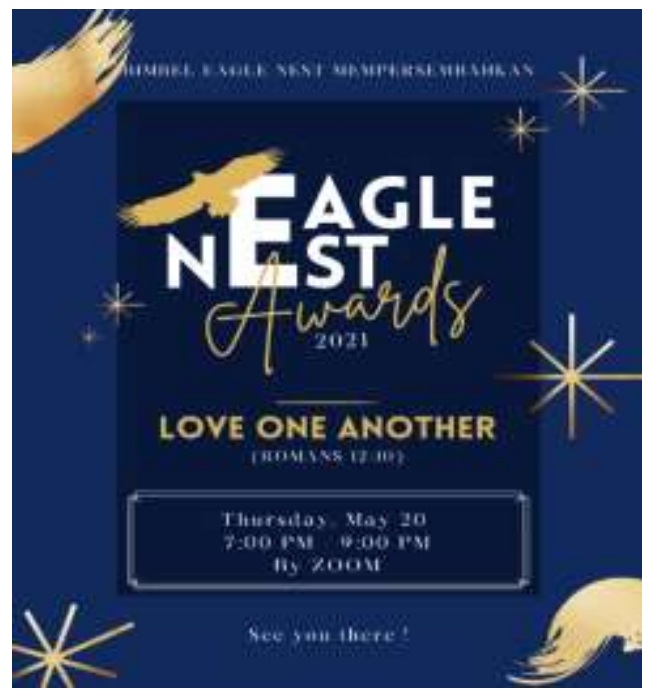

Gambar 10. Acara Kebersamaan 20 Mei 2021

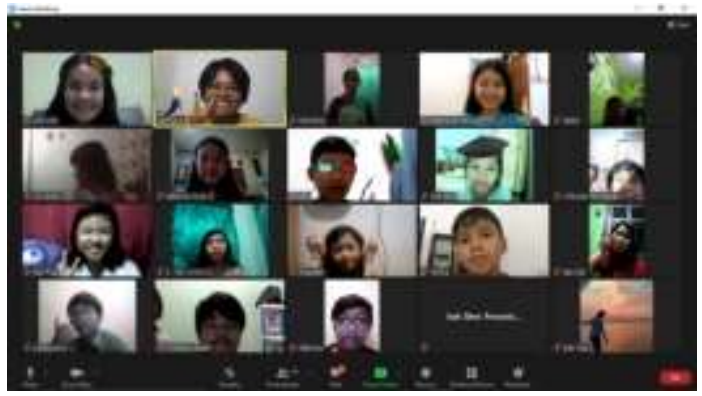

Gambar 11. Acara Kebersamaan 20 Mei 2021 


\section{Hasil Kegiatan Bimbingan Belajar}

Kegiatan PkM Bimbingan belajar Eagle

Nest yang bekerjasama dengan Gereja Baptis Indonesia mendapatkan sambutan yang sangat baik dari orang tua termasuk siswa-siswa yang dilayani. Hal ini disebabkan oleh hasil belajar siswa di sekolah yang mulai meningkat, (diutarakan oleh orang tua siswa). Dampak yang terlihat juga adalah adanya peningkatan jumlah siswa yang datang biasanya belasan siswa saja kemudian meningkat ke angka 27 siswa (lihat tabel pelaksanaan bimbingan belajar). Dampak lainnya juga adalah siswa terbiasa belajar seusai jam sekolah, tidak hanya itu siswa mendapatkan kehidupan sosial melalui bimbingan belajar ini. Mereka mendapatkan komunitas belajar dengan teman sejawat sekalipun lewat daring.

Terdapat dampak positif dalam psikologis anak, khususnya dalam hal motivasi belajar. Orang tua bahkan tutor mengatakan bahwa ada anak yang awalnya malas-malasan, namun belakangan jauh lebih aktif, mau belajar, dan antusias bertanya kepada tutor saat bimbingan belajar berlangsung. Hal ini sejalan juga dengan laporan mingguan PiC Tutor bahwa siswa mulai tidak terlambat untuk ikut bimbingan belajar. Setiap minggunya $\mathrm{PiC}$ tutor wajib melaporkan kepada dosen yang bertanggungjawab dalam bimbingan belajar ini termasuk mengirimkan foto-foto pelaksanaan bimbingan belajar.

Berdasarkan hasil yang baik dan juga respon dari orang tua siswa dan siswa, maka pelaksanaan PkM Bimbingan Belajar Eagle Nest ini akan dilanjutkan ke periode semester berikutnya, tentunya dengan mengevaluasi juga kekurangan untuk menjadi perbaikan semester berikutnya. Berdasarkan hasil evaluasi terdapat beberapa kekurangan dari PkM ini, dan diharapkan akan menjadi perbaikan untuk pelaksanaan kelanjutan dari bimbingan belajar ini, yaitu: 1) Diperlukannya dana untuk menopang paket data internet mahasiswa sebagai tutor; 2) Diperlukan dana untuk membayar paket berlangganan zoom meeting agar dapat melebihi durasi 40 menit; 3) Perlu dilakukan minimal 4 kali pertemuan setiap minggunya dan membagi anak-anaknya menjadi dua kelompok; 4) Penambahan mahasiswa yang akan mengajar di bimbingan belajar Eagle Nest.

Beberapa saran dari tutor dan juga orang tua agar bimbingan belajar berikutnya dapat melaksanakan acara kebersamaan yang juga fokus pada seni dan tari untuk mengasah bakat siswa.

Hasil kegiatan bimbingan belajar pada tingkat SD adalah siswa dapat membaca dan menulis dengan benar. Pada tingkat SMP dan SMA difokuskan pada peningkatan kemampuan pelajaran matematika, IPA, dan bahasa Inggris. Berdasarkan umpan balik secara informal dari peserta bimbel dan pihak gereja menyatakan bahwa siswa sangat terbantu dengan adanya kegiatan belajar ini. PkM ini berlanjut ke semester berikutnya yaitu semester ganjil 2021/2022 dan tahun ajaran baru 2021/2022.

\section{KESIMPULAN}

Berdasarkan hasil kegiatan bimbingan belajar yang telah dilakukan, kesimpulan yang dapat diambil adalah kegiatan ini bermanfaat bagi siswa untuk meningkatkan kemampuan membaca, menulis, dan berhitung bagi siswa TK-SD dan juga meningkatkan kemampuan Matematika, IPA, dan Bahasa Inggris untuk siswa SMP-SMA.

Kegiatan ini disarankan untuk dilanjutkan pada semester mendatang dengan persiapan yang lebih baik dalam hal mempersiapkan tutor dan alat penilaian untuk mengukur ketercapaian manfaat terhadap siswa yang diajar. Selain itu, perlu dicakupkan manfaat kegiatan ini untuk mahasiswa guru dan juga sekaligus alat penilaian untuk mengukur ketercapaian tersebut. Fasilitas dan bahan pembelajaran untuk menunjang pembelajaran siswa harus diperhatikan.

\section{UCAPAN TERIMAKASIH}

Penulis hendak mengucapkan banyak terima kasih kepada:

1. Baptis Indonesia, yang sudah menginisiasi Bimbingan Belajar Eagle Nest yang berlangsung dan memperkenalkan dengan dan memperkenalkan kepada UPH-Teachers College.

2. Mahasiswa Pendidikan Guru Sekolah Dasar (PGSD) Fakultas Ilmu Pendidikan Universitas Pelita Harapan sebagai tutor, yang sudah terlibat melayani dan mendidik siswa-siswi yang menjadi peserta Bimbingan Belajar ini. 
3. LPPM UPH dari pimpinan dan staf, yang sudah sangat membantu memfasilitasi kegiatan pengabdian kepada masyarakat ini, dengan proposal PM-05-K/FIP/V/2021.

Tanpa bantuan dan kerja sama ini, maka tidak mungkin Bimbingan Belajar Eagle Nest dapat dilaksanakan. Terlebih lagi tidak mungkin ada manfaat yang dapat dirasakan oleh siswa-siswa peserta didik dari Bimbingan Belajar ini.

\section{REFERENSI}

Bakhtiyar. (2019). Peran Keluarga Sebagai Pendamping Belajar Anak Dalam Meraih Prestasi Belajar Di Sekolah Melalui Pelayanan Layanan Jasa Informasi Perpustakaan: Suatu Kajian Dalam Perspektif Sosio Kultural. Jurnal Perpustakaan Universitas Airlangga. Vol. 8.

Chotimah, L. Nur., dkk. (2017). Pengaruh Status Sosial Ekonomi Orang Tua Terhadap Prestasi Belajar Siswa. Jurnal Pendidikan Ekonomi. Vol. 11.

Roediger, Henry L., (2013). Applying Cognitive Psychology to Education. St. Louis: Washington University. https://www.researchgate.net/publication/27359295 6

Nurdyansyah \& Fahyuni, Eni. (2016). Inovasi Model Pembelajaran. Nizamia Learning Center Sidoarjo.

Oktavian, R., \& Aldya, R. F. (2020). Efektivitas Pembelajaran Daring Terintegrasi di Era Pendidikan 4.0. Didaktis: Jurnal Pendidikan Dan Ilmu Pengetahuan, 20(2), 129-135. https://doi.org/10.30651/didaktis.v20i2.4763
Qomaruddin (2017). Pentingnya Pendampingan Orang Tua Terhadap Pendidikan Anak. E-journal Kopertais.

Rehalat, Aminah. (2014). Model Pembelajaran Pemrosesan Informasi. Jurnal Pendidikan Ilmu Sosial. Vol. 3.

Rohaeti, dkk. (2019). Program Pendampingan Berbasis Kearifan Lokal Desa, Adat Desa Senaru Dalam Meningkatkan Motivasi Belajar Anak-anak Desa Adat Senaru. Jurnal Pengabdian Kepada Masyarakat. Vol. 2.

Santrock, John W. (2011). Psikologi Pendidikan. McGraw-Hill Company, Inc.

Simanjuntak, F. (2020). Konsep Dosa Menurut Pandangan Paulus. Jurnal Teologi Dan Pendidikan Agama Kristen, 3(2), 17-28. https://doi.org/10.31219/osf.io/7vr8d

Sourial, N., Longo, C., Vedel, I., \& Schuster, T. (2018). Daring to draw causal claims from non-randomized studies of primary care interventions. Jurnal Pendidikan Administrasi Perkantoran (JPAP), 35(5), 639-643. https://doi.org/10.1093/fampra/cmy005

Suryaningsih, Yeni. (2017). Pembelajaran Berbasis Praktikum Sebagai Sarana Siswa Untuk Berlatih Menerapkan Keterampilan Proses Sains Dalam Materi Biologi. Jurnal Pendidikan Biologi. Vol. 2.

Zaini, Ahmad dkk. (2015). Pengaruh StatusSosial Ekonomi Dan Tingkat Pendidikan Orang Tua Terhadap Minat Studi Lanjut Siswa Kelas XII Di Ma Miftahul Huda Cendono Purwosari Kabupaten Pasuruan. Jurnal Penelitian dan Pendidikan IPS (JPPI. Vol. 3. 